\title{
Front Matter: Volume 11897
}

, "Front Matter: Volume 11897," Proc. SPIE 11897, Optoelectronic Imaging and Multimedia Technology VIII, 1189701 (27 October 2021); doi:

10.1117/12.2619255

SPIE. Event: SPIE/COS Photonics Asia, 2021, Nantong, Jiangsu, China 


\title{
PROCEEDINGS OF SPIE
}

\section{Optoelectronic Imaging and Multimedia Technology VIII}

\author{
Qionghai Dai \\ Tsutomu Shimura \\ Zhenrong Zheng \\ Editors
}

\section{0-12 October 2021 \\ Nantong, China}

\author{
Sponsored by \\ SPIE \\ COS-Chinese Optical Society
}

Cooperating Organizations

Tsinghua University (China) - Peking University (China) - University of Science and Technology of China (China) • Zhejiang University (China) • Tianjin University (China) Beijing Institute of Technology (China) - Beijing University of Posts and Telecommunications (China) - Nankai University (China) Changchun University of Science and Technology (China) - University of Shanghai for Science and Technology (China) - Capital Normal University (China) - Huazhong University of Science and Technology (China) • Beijing Jiaotong University (China) - China Jiliang University (China) Shanghai Institute of Optics and Fine Mechanics, CAS (China) - Changchun Institute of Optics, Fine Mechanics and Physics, CAS (China) - Institute of Semiconductors, CAS (China) • Institute of Optics and Electronics, CAS (China) - Institute of Physics, CAS (China) - Shanghai Institute of Technical Physics, CAS (China) - China Instrument and Control Society (China) - Japan Optical Society (Japan) - Optical Society of Korea (Korea, Republic of) - Australia and New Zealand Optical Society (Australia) - Optics and Photonics Society of Singapore (Singapore) - European Optical Society

\section{Supporting Organizations}

China Association for Science and Technology (CAST) (China) - Department of Information of National Nature Science Foundation, China (NSFC) (China)

Published by

SPIE

Volume 11897 
The papers in this volume were part of the technical conference cited on the cover and title page. Papers were selected and subject to review by the editors and conference program committee. Some conference presentations may not be available for publication. Additional papers and presentation recordings may be available online in the SPIE Digital Library at SPIEDigitalLibrary.org.

The papers reflect the work and thoughts of the authors and are published herein as submitted. The publisher is not responsible for the validity of the information or for any outcomes resulting from reliance thereon.

Please use the following format to cite material from these proceedings:

Author(s), "Title of Paper," in Optoelectronic Imaging and Multimedia Technology VIII, edited by Qionghai Dai, Tsutomu Shimura, Zhenrong Zheng, Proc. of SPIE 11897, Seven-digit Article CID Number (DD/MM/YYYY); (DOI URL).

ISSN: 0277-786X

ISSN: 1996-756X (electronic)

ISBN: 9781510646438

ISBN: 9781510646445 (electronic)

Published by

SPIE

P.O. Box 10, Bellingham, Washington 98227-0010 USA

Telephone +1 3606763290 (Pacific Time)

SPIE.org

Copyright @ 2021 Society of Photo-Optical Instrumentation Engineers (SPIE).

Copying of material in this book for internal or personal use, or for the internal or personal use of specific clients, beyond the fair use provisions granted by the U.S. Copyright Law is authorized by SPIE subject to payment of fees. To obtain permission to use and share articles in this volume, visit Copyright Clearance Center at copyright.com. Other copying for republication, resale, advertising or promotion, or any form of systematic or multiple reproduction of any material in this book is prohibited except with permission in writing from the publisher.

Printed in the United States of America by Curran Associates, Inc., under license from SPIE.

Publication of record for individual papers is online in the SPIE Digital Library.

\section{SPIE. DIGITAL}

Paper Numbering: A unique citation identifier (CID) number is assigned to each article in the Proceedings of SPIE at the time of publication. Utilization of CIDs allows articles to be fully citable as soon as they are published online, and connects the same identifier to all online and print versions of the publication. SPIE uses a seven-digit CID article numbering system structured as follows:

- The first five digits correspond to the SPIE volume number.

- The last two digits indicate publication order within the volume using a Base 36 numbering system employing both numerals and letters. These two-number sets start with 00, 01, 02, 03, 04, 05, 06, 07, 08, 09, 0A, OB ... 0Z, followed by 10-1Z, 20-2Z, etc. The CID Number appears on each page of the manuscript. 


\section{Contents}

\section{COMPUTER VISION AND GRAPHICS}

$1189702 \quad$ A neural network for underwater polarization dehazing imaging [1 1897-2]

$1189703 \quad$ Focusing of scattering light based on wavefront feedback shaping technology [11897-3]

1189704 Simultaneous image deblurring and inpainting via convolutional sparse coding [11897-4]

1189705 An adaptive obstacle avoidance algorithm of collaborative unmanned vehicles in dynamic scenes with monocular cameras [11897-5]

1189706 Wide field-of-view waveguide coupling metasurfaces used on augmented reality system [11897-6]

HYPERSPECTRAL AND SINGLE-PIXEL IMAGING

1189708 Single-pixel multispectral imaging based on macropixel segmentation method [1 1897-8]

1189709 Study of perovskite mono-crystals growth based on micro-hyperspectral imaging [11897-9]

11897 OA Study of image processing of fluorescent molecules based on microscopic hyperspectral with transmission mode [11897-10]

BIOMEDICAL IMAGING AND MICROSCOPY

11897 OB Medical CT image amplification and reconstruction system based on deep learning (Invited Paper) [11897-11]

11897 OD Wavefront modulation with spatial light modulator for Fourier ptychographic microscopy [11897-13]

11897 OF Image reconstruction from optical speckle pattern based on deep learning [11897-37]

\section{POSTER SESSION}

11897 OK Thin filament pyrometry to measure the butane air flame combustion flame [11897-18] 
$11897 \mathrm{OL} \quad$ Convolutional sparse coding and directional gradient prior based method for single image rain streak removal [11897-19]

11897 OM Single frame infrared small target detection based on local gradient and directional curvature [1 1897-20]

1189700 Color correction and dynamic range expansion of underwater images based on light field technology [11897-22]

11897 OP Z Zoom imaging system using liquid crystal lens array [1 1897-23]

$118970 Q \quad$ Few-shot deep model of waste classification based on model agnostic meta learning [1 1897-24]

11897 OR Similarity perception Siamese network for real-time object tracking [1 1897-25]

11897 OS Point cloud registration algorithm based on curvature and direction vector threshold [1 1897-26]

11897 ОT An improved method based on TwIST and dual-camera design for hyperspectral image reconstruction [11897-27]

11897 OU Underwater image enhancement based on computational imaging and deep learning [1 1897-28]

11897 OV Spherical triangle mesh representation and multi-channel residual graph convolution network based blind omnidirectional image quality assessment [1 1897-29]

$118970 Z$ Multi-feature fusion gaze estimation based on attention mechanism [1 1897-33]

$1189710 \quad$ Enhanced phase retrieval for non-ideal in-line phase contrast x-ray imaging based on deep learning [1 1897-34]

$1189711 \quad$ Accurate multi-image super-resolution using deep residual networks [11897-35]

$1189712 \quad$ Eliminating multi-aberrations in optical imaging systems with scattering media [11897-36]

1189713 Denoising of event-based sensors with deep neural networks [1 1897-38]

1189715 The realistic rendering of scenes defined by the cloud of points [1 1897-40]

1189716 Evaluation of deep-learning-based myocardial infarction quantification using Segment CMR software [1 1897-41]

1189717 Effect of the regularization hyperparameter on deep-learning-based segmentation in LGE-MRI [1 1897-42]

11897 1A Real-time tracking of surrounding objects in augmented and mixed reality applications [1 1897-45] 